\title{
Mineralogical composition of cryoconite on glaciers in northwest Greenland
}

\author{
Naoko NAGATSUKA ${ }^{1 *}$, Nozomu TAKEUCHI ${ }^{2}$, Jun UETAKE $^{1}$ and Rigen SHIMADA ${ }^{2}$ \\ 1 National Institute of Polar Research, Tachikawa, Tokyo 190-8518, Japan \\ *nagatsuka.naoko@nipr.ac.jp \\ 2 Department of Earth Sciences, Graduate School of Science, Chiba University, Inage-ku, Chiba 263-8522, Japan
}

(Received March 31, 2014; Revised manuscript accepted September 8, 2014)

\begin{abstract}
The mineralogical composition of cryoconite on a glacial surface was investigated on six glaciers in northwest Greenland (Qaanaaq, Qaqortaq, Tugto, Bowdoin, Sun, and Scarlet Heart). The X-ray diffraction analysis showed that the cryoconites mainly contained seven silicate minerals: hornblende, quartz, potassium feldspar, plagioclase, illite, kaolinite, and chlorite. Semi-quantitative mineralogical analysis of the silicate mineral composition on the Qaanaaq Glacier showed little variation among the samples collected from five different elevations. This indicates that the minerals on the glacier were probably dominated by dust from a unique source, which is recently transported from local sediments, including soil and moraine. On the other hand, the mineral composition varied significantly among the glaciers. Based on the clay mineral content, the glaciers could be classified into three groups. Type A: high clay mineral content, composed of illite and kaolinite, found on Qaanaaq, Qaqortaq, and Tugto; Type B: high clay mineral content, composed of only kaolinite, found on Sun; and Type C: lower clay mineral content, composed of only kaolinite, found on Bowdoin and Scarlet Heart. The geographical distribution of the types of glaciers did not correspond with the geology in this area, indicating that the mineralogical composition is not determined just by the geological conditions around glaciers, but also by other factors, such as the redistribution of sediments by glacial, fluvial, or coastal processes.
\end{abstract}

Key words: cryoconite, mineral composition, X-ray diffraction analysis, glacial microbe, darkening of glaciers

\section{Introduction}

Mineral dust in snow and ice is an important factor affecting glacial melting. The mineral dust on the ablation ice of glaciers is often contained in cryoconite, which is an aggregate of minerals, organic matter, and microbes living on the glaciers. The dark color of the minerals and organic matter in cryoconite can reduce the albedo of glaciers and increase their melting (Kohshima et al., 1993; Wientjes et al., 2011). For example, Oerlemans et al. (2009) reported that the accumulation of mineral and biogenic dust (cryoconite) has substantially darkened a glacier in Switzerland since 2003, which is likely to cause surface albedo reduction and the removal of ice from the glacier. Therefore, the abundance and composition of mineral dust on the glaciers can affect the mass balance of glaciers.

Mineral dust may also affect the microbial production and community structure on glaciers. Previous studies report that there are abundant microbes on glaciers, such as filamentous cyanobacteria and green algae (Takeuchi et al., 2001; Uetake et al., 2010). Because the glacial microbes are likely to incorporate nutrients from mineral particles as well as dissolved components in snow and ice (Fjerdingstad, 1973; Wientjes et al., 2011; Nagatsuka et al., 2010), the minerals on glaciers could affect their biomass and the species of the microbes via the nutrient conditions. Thus, it is important to study the minerals in cryoconite to understand the biological activity and recent changes in glacial mass balance.

In recent years, the darkening of glaciers associated with cryoconite abundance has been reported in the Greenland ice sheet. For example, a large area of the ice surface is progressively darkening because of increases in the amount of cryoconite, and the dark region is expanding over the ablation zone of the western Greenland ice sheet (Wientjes and Oerlemans, 2010). Wientjes et al. (2011) analyzed the mineral dust in cryoconite in the dark region, and revealed that it originated from both recent local deposition and old dust deposits from outcropping ice. The ice-sheet margin in northwestern Greenland also shows that the glacier ice surface is darkening in the upper ablation zone caused by the accumulation of cryoconite that contains minerals derived from local sources as well as dust deposited during Pleistocene glaciation (Bøggild et al., 2010). With climatic warming, a rising equilibrium line could expose new areas of the 
dark upper ablation zone and increase the melting and thinning of the Greenland ice sheet further (Bøggild et al., 2010). Therefore, the albedo reduction due to the darkening effect of cryoconite on glaciers plays an important role in the glacial melting in Greenland. Although cryoconite on glaciers in Greenland has been studied physically, chemically, and biologically (Anesio et al., 2009; Hodson et al., 2010; Stibal et al., 2012), mineralogical information about the cryoconite is still limited.

Recent global environmental change could increase the darkening of glaciers in Greenland. Previous studies show that the minerals in cryoconite on Greenlandic glaciers are likely to be derived from local sources rather than from eolian dust from distant areas (Bøggild et al., 2010; Wientjes et al., 2011). However, most of the Earth's surface has changed rapidly because of recent climate warming and human activities (IPCC, 2007), which may result in changes in atmospheric transport and sources of mineral dust on the glaciers. The retreating ice will expose more sediment in the proglacial area, delivering greater quantities of fine sediments to the floodplain than at present (Jansson et al., 2005; Sugden et al., 2009). Bullard and Austin (2011) report that reworking of the proglacial floodplain in Kangerlussuaq, West Greenland, during ice retreat may also make more material available for eolian transport. Furthermore, Kurosaki and Mikami (2003) showed that a remarkable increase in dust outbreaks has occurred in East Asian deserts, which is vast source of eolian dust, over three recent years (2000-
2002) compared with the previous seven years (19931999). The dust from such Asian deserts is also transported to Greenland across the ocean (VanCuren and Cahill, 2002; Svensson et al., 2000). These frequent dust outbreaks could cause an increase in the eolian dust deposits on Greenlandic glaciers, leading to further albedo reduction and changes in the nutrient conditions for glacial microbes. Although glacier shrinkage in Greenland is mainly caused by the effect of global warming, it is also likely to be affected by the albedo reduction effects of the minerals in cryoconite on the glaciers.

This paper aims to describe the mineralogical composition of cryoconite on glaciers in northwest Greenland. The samples of cryoconite were collected from several sites on the Qaanaaq Glacier and were semi-qualitatively analyzed. Furthermore, the samples collected from five other glaciers in geographically separated regions were also analyzed. Variations in the mineralogical compositions in the cryoconites are discussed in terms of the spatial distribution on the glaciers and the geographical differences among the regions.

\section{Samples and analytical method}

We analyzed minerals in cryoconite collected from geographically separated six glaciers in northwest Greenland: Qaanaaq Glacier (QA), Qaqortaq Glacier (QQ), Tugto Glacier (TUG), Bowdoin Glacier (BD), Sun Glacier

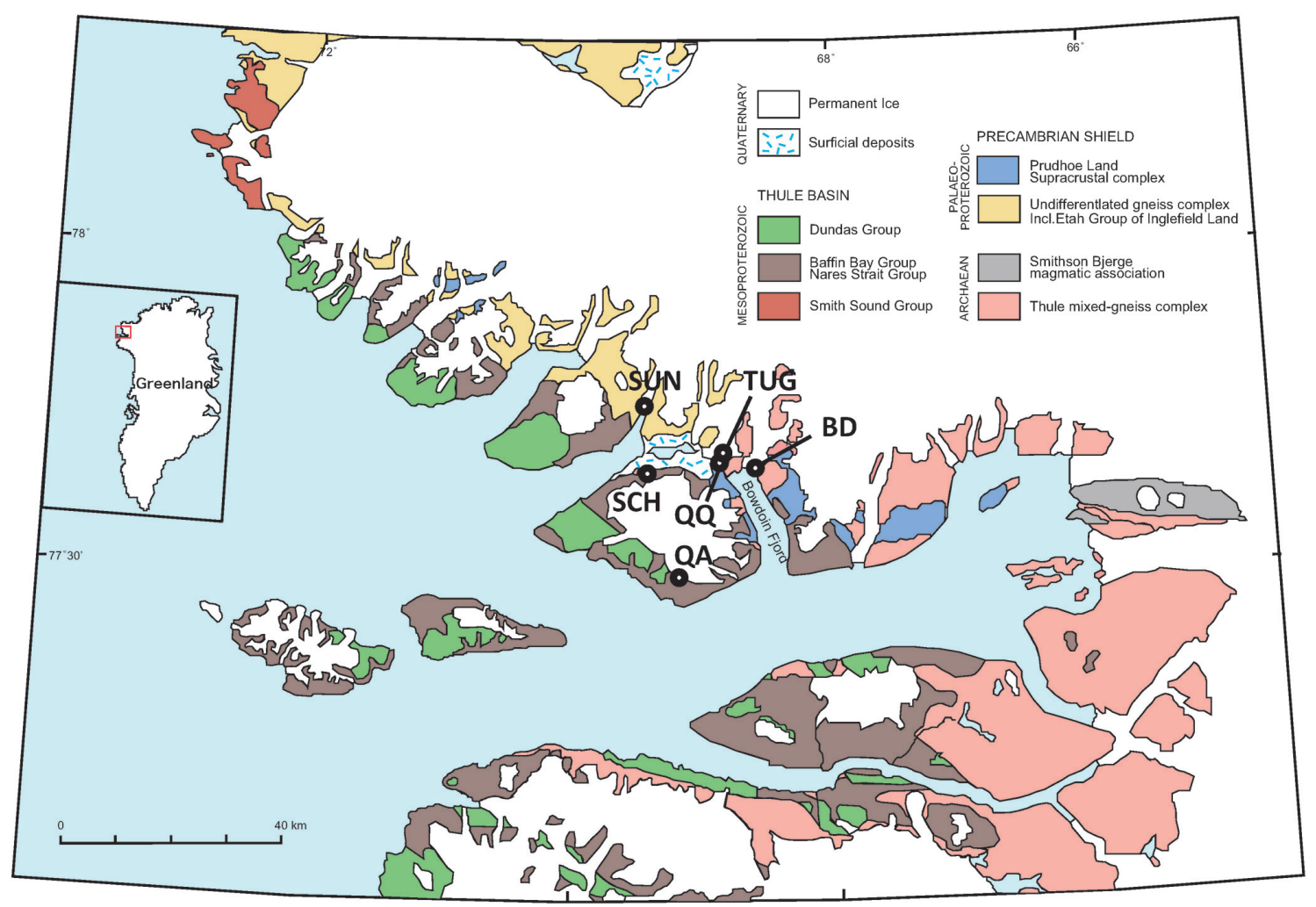

Fig. 1. Geological map of northwest Greenland modified from Thomassen et al. (2002) showing the glaciers where cryoconite samples were collected. (QA: Qaanaaq Glacier, QQ: Qaqortaq Glacier, TUG: Tugto Glacier, BD: Bowdoin Glacier, SUN: Sun Glacier, SCH: Scarlet Heart Glacier) 
Table 1. Description of sample of cryoconite, soil, and moraine on and around the the glaciers in northwest Greenland.

\begin{tabular}{llllll}
\hline $\begin{array}{l}\text { Glacier } \\
\text { (abbreviation) }\end{array}$ & Lat, Long & Site & Sample type & $\begin{array}{l}\text { Elevation } \\
\text { (m a.s.l) }\end{array}$ & Sampling date \\
\hline Qaanaaq (QA) & $77^{\circ} 30^{\prime} \mathrm{N}, 69^{\circ} 15^{\prime} \mathrm{W}$ & QA1 & Cryoconite (ice) & 247 & 22 July 2012 \\
& $77^{\circ} 30^{\prime} \mathrm{N}, 69^{\circ} 12^{\prime} \mathrm{W}$ & QA2 & Cryoconite (ice) & 441 & 22 July 2012 \\
& $77^{\circ} 30^{\prime} \mathrm{N}, 69^{\circ} 08^{\prime} \mathrm{W}$ & QA3 & Cryoconite (ice) & 668 & 18 July 2012 \\
& $77^{\circ} 30^{\prime} \mathrm{N}, 69^{\circ} 07^{\prime} \mathrm{W}$ & QA4 & Cryoconite (ice) & 778 & 18 July 2012 \\
& $77^{\circ} 31^{\prime} \mathrm{N}, 69^{\circ} 06^{\prime} \mathrm{W}$ & QA5 & Cryoconite (ice) & 939 & 19 July 2012 \\
& $\mathrm{~N} / \mathrm{A}$ & QAS & Soil & NA & 22 July 2012 \\
& $77^{\circ} 36^{\prime} \mathrm{N}, 69^{\circ} 42^{\prime} \mathrm{W}$ & QAM & Moraine & 202 & 22 July 2012 \\
Qaqortaq (QQ) & $77^{\circ} 67^{\prime} \mathrm{N}, 68^{\circ} 82^{\prime} \mathrm{W}$ & QQ & Cryoconite (ice) & 28 & 28 July 2012 \\
Tugto (TUG) & $77^{\circ} 68^{\prime} \mathrm{N}, 68^{\circ} 85^{\prime} \mathrm{W}$ & TUG & Cryoconite (ice) & 54 & 27 July 2012 \\
Bowdoin (BD) & $77^{\circ} 40^{\prime} \mathrm{N}, 68^{\circ} 35^{\prime} \mathrm{W}$ & BD & Cryoconite (ice) & 48 & 26 July 2013 \\
Sun (SUN) & $77^{\circ} 47^{\prime} \mathrm{N}, 69^{\circ} 27^{\prime} \mathrm{W}$ & SUN & Cryoconite (ice) & 102 & 20 July 2013 \\
Scarlet Heart (SCH) & $77^{\circ} 40^{\prime} \mathrm{N}, 69^{\circ} 27^{\prime} \mathrm{W}$ & SCH & Cryoconite (ice) & 140 & 21 July 2013 \\
\hline
\end{tabular}

(SUN), and Scarlet Heart Glacier (SCH, Fig. 1). Samples were collected out in summer 2012 and 2013 on the glaciers (Table 1). Cryoconite samples were collected from the ice surface of the glaciers in ablation area. The samples from Qaanaaq Glacier were collected at five different elevation sites ranging from $247 \mathrm{~m}$ (QA1) to $939 \mathrm{~m}$ a.s.l (QA5), whereas those of other glaciers were collected at only one site near the terminus $(28-140 \mathrm{~m})$. The samples of cryoconite were randomly collected at each site on the glaciers with a stainless steel scoop and stored in clean $30 \mathrm{~mL}$ polyethylene bottles. Because the minerals on the glaciers are likely to be well mixed by ice movement and running melt water on the surface, we assumed that their composition was uniform within a site. Moraine and soil around the glaciers were also collected to evaluate their contribution to the dust.

The mineralogical composition of cryoconites on the glaciers was identified by powder X-ray diffraction analysis (XRD) using a Rigaku Geigerflex RAD 11-B diffractometer at Chiba University, Japan. XRD analysis is an effective method for identifying and quantifying minerals and is used in loess studies and provenance identification of dust in ice cores (Svensson et al., 2000). In XRD analysis, each mineral shows a specific diffraction spectrum, thus enabling mineral identification by comparing the peak position and peak intensity of measured minerals with that of a standard mineral.

Samples were dried at $60^{\circ} \mathrm{C}$ and then powdered with an agate mortar. The X-ray target was $\operatorname{CuK} \alpha$, the tube voltage was $40 \mathrm{kV}$, and the tube current was $25 \mathrm{~mA}$. Scans were performed from $2^{\circ}$ to $40^{\circ}(2 \theta)$ at a rate of $2^{\circ}$ \% $\min (2 \theta)$. Our analysis followed the method published by Nagatsuka et al. (2010). Moreover, quantitative analyses were also performed following the method described by Chung (1974). The peak height ratio of each mineral to that of quartz was compared with those from reference minerals, after which the semi-quantitative proportion of each sample was obtained. Although the chlorite peaks have different intensities for different compositions because this mineral forms solid solutions, we used the $\mathrm{Fe}-\mathrm{Mg}$ chlorite peaks for the quantification. This method, although not so precise, gives a rough estimate of the modal composition as a weight percentage (quantification precision has been estimated to be 3-8\% in Chung (1975)).

\section{Results}

\section{3-1. XRD spectra of mineral dust}

The XRD spectra of cryoconite samples from the Qaanaaq Glacier were generally similar, and showed peaks for several silicate minerals (Fig. 2). The peaks in all the cryoconite samples were identified as hornblende $\left(10.5^{\circ}\right)$, quartz $\left(26.7^{\circ}\right)$, potassium feldspar $\left(27.2^{\circ}\right)$, plagioclase $\left(28.2^{\circ}\right)$, and clay minerals, such as illite $\left(8.9^{\circ}\right)$ and kaolinite $\left(12.5^{\circ}, 25.2^{\circ}\right)$. There was only one distinctive peak that appeared in the spectra of the middle and upper part of the glacier (QA3 to QA5), which was chlorite $\left(6.0^{\circ}, 12.5^{\circ}\right.$, $18.9^{\circ}$ ). Although peaks around $12.5^{\circ}$ and $25.2^{\circ}$ can also be identified as vermiculite or smectite, the peaks in this study are likely to be kaolinite and chlorite because previous studies have shown that minerals in ice or cryoconite in Greenland rarely contain vermiculite or smectite (Svensson et al., 2000; Wientjes et al., 2011).

The spectra of soil and moraine around the Qaanaaq Glacier differed from those of the cryoconite on the glacier (Fig. 2). The spectra showed hornblende, quartz, plagioclase, illite, and kaolinite peaks, and the spectrum of soil also showed a peak for potassium feldspar. However, the intensities of the quartz peaks were more than six times greater in the soil and moraine than in the cryoconite.

The XRD spectra of cryoconites on the five other glaciers in northwest Greenland were substantially different from those on the Qaanaaq Glacier, and also showed variations among the glaciers (Fig. 3). For example, the spectrum of the Scarlet Heart Glacier showed only quartz, potassium feldspar, plagioclase, and kaolinite peaks, and the spectra of the Bowdoin and Sun Glacier showed hornblende peaks in addition to these peaks.

\section{3-2. Semi-quantitative estimation of mineral dust}

Semi-quantitative analysis of the XRD curves showed that the abundance of quartz and plagioclase was higher 
(31-36\%, 16-29\%), but that of chlorite was the lowest $(0-4 \%)$ in the silicate minerals of all of the cryoconite samples from the Qaanaaq Glacier. The abundance of

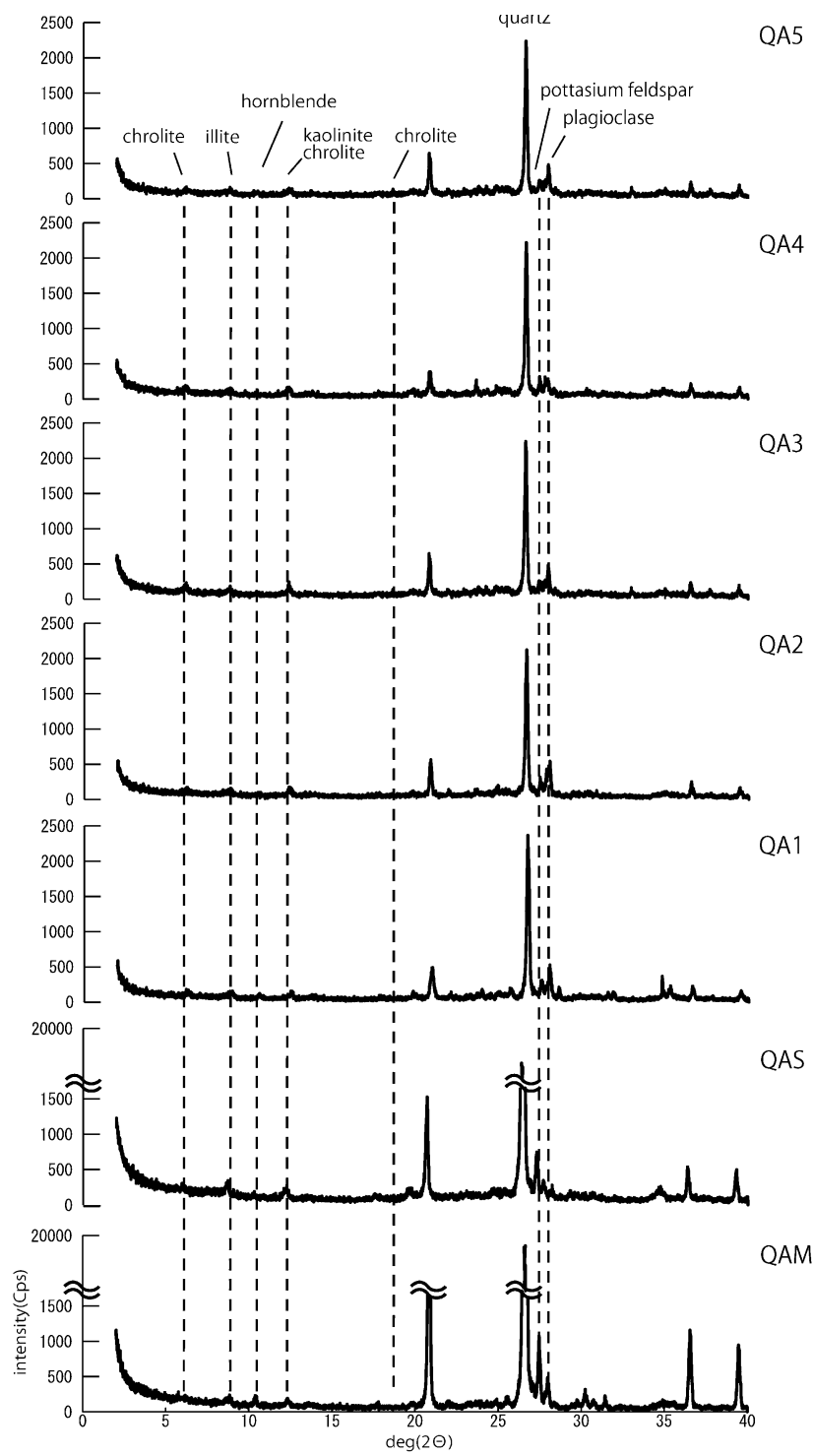

Fig. 2. X-ray diffraction (XRD) spectra of minerals in cryoconite, soil, and moraine on and around Qaanaaq Glacier. hornblende (8-13\%), potassium feldspar (8-14\%), and two clay minerals, illite and kaolinite (0-15\%), were generally low and similar to each other.

There were few variations in the mineralogical composition among the samples collected from five different elevation sites on the Qaanaaq Glacier. However, the cryoconite collected from the middle part of the glacier (QA3) differed slightly from those of the other four sites (QA1-QA2, QA4-QA5). The mineral composition in the cryoconite on the site QA3 had a higher clay

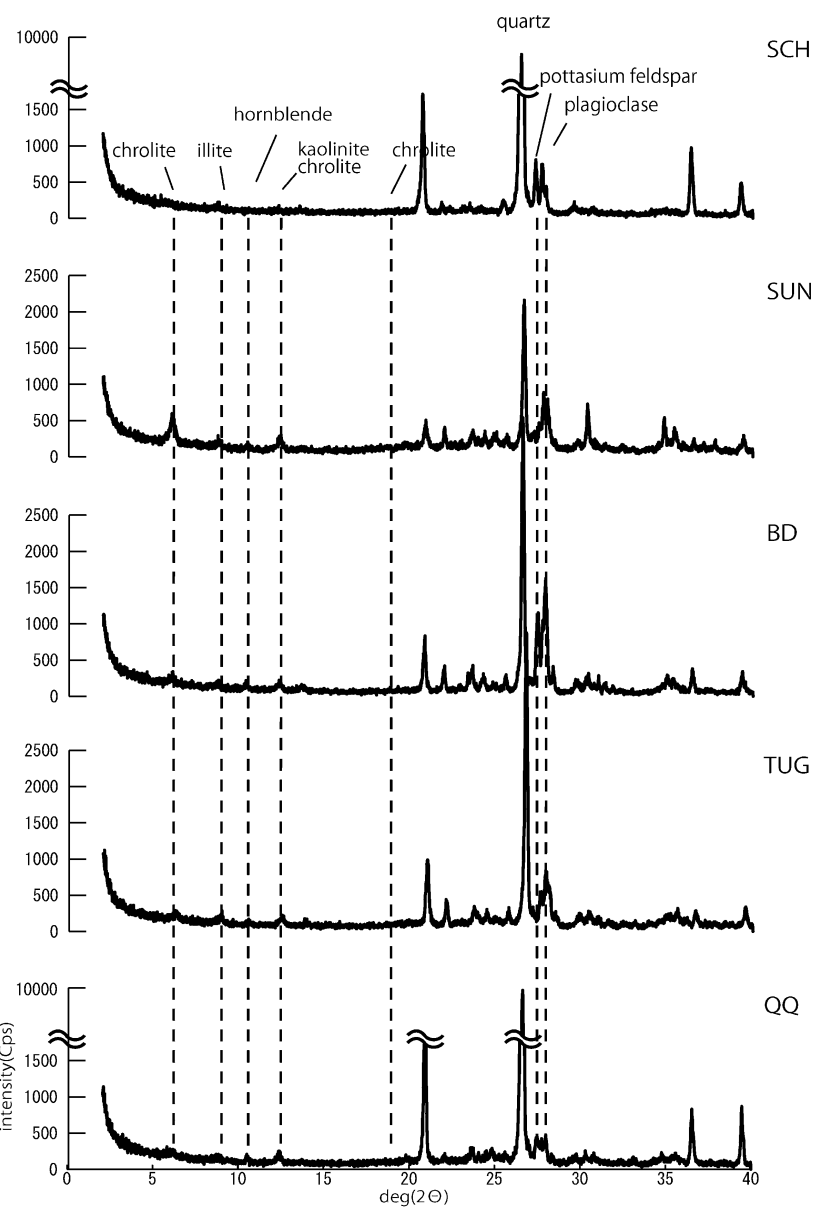

Fig. 3. XRD spectra of minerals in cryoconites on glaciers in Greenland.

Table 2. Minerals proportion in cryoconite, soil, and, moraine on and around the glaciers in northwest Greenland.

\begin{tabular}{lccccccc}
\hline Sample & $\begin{array}{c}\text { illite } \\
(\%)\end{array}$ & $\begin{array}{c}\text { kaolinite } \\
(\%)\end{array}$ & $\begin{array}{c}\text { chlorite } \\
(\%)\end{array}$ & $\begin{array}{c}\text { hornblende } \\
(\%)\end{array}$ & $\begin{array}{c}\text { plagioclase } \\
(\%)\end{array}$ & $\begin{array}{c}\text { potassium } \\
\text { feldspar } \\
(\%)\end{array}$ & $\begin{array}{c}\text { quartz } \\
(\%)\end{array}$ \\
\hline QA1 & 7.6 & 7.6 & 0.0 & 12.7 & 26.1 & 12.7 & 33.4 \\
QA2 & 7.7 & 10.3 & 0.4 & 8.0 & 29.4 & 13.1 & 31.1 \\
QA3 & 10.9 & 15.0 & 3.3 & 7.8 & 23.6 & 8.2 & 31.1 \\
QA4 & 9.2 & 10.9 & 1.7 & 12.8 & 15.6 & 13.8 & 36.0 \\
QA5 & 9.7 & 8.1 & 3.7 & 10.9 & 25.8 & 7.8 & 33.9 \\
QAS & 6.5 & 2.5 & 0.0 & 4.4 & 3.5 & 12.4 & 70.6 \\
QAM & 3.0 & 1.9 & 0.3 & 7.9 & 11.0 & 0.0 & 75.9 \\
QQ & 3.4 & 6.1 & 0.9 & 8.9 & 9.5 & 6.7 & 64.6 \\
TUG & 10.0 & 7.5 & 0.9 & 9.0 & 23.0 & 11.9 & 37.8 \\
BD & 0.0 & 4.3 & 0.0 & 8.7 & 39.0 & 25.8 & 22.2 \\
SUN & 0.0 & 15.0 & 0.0 & 15.7 & 34.4 & 9.4 & 25.5 \\
SCH & 0.0 & 2.9 & 0.0 & 0.0 & 17.7 & 17.8 & 61.6 \\
\hline
\end{tabular}


(\%)
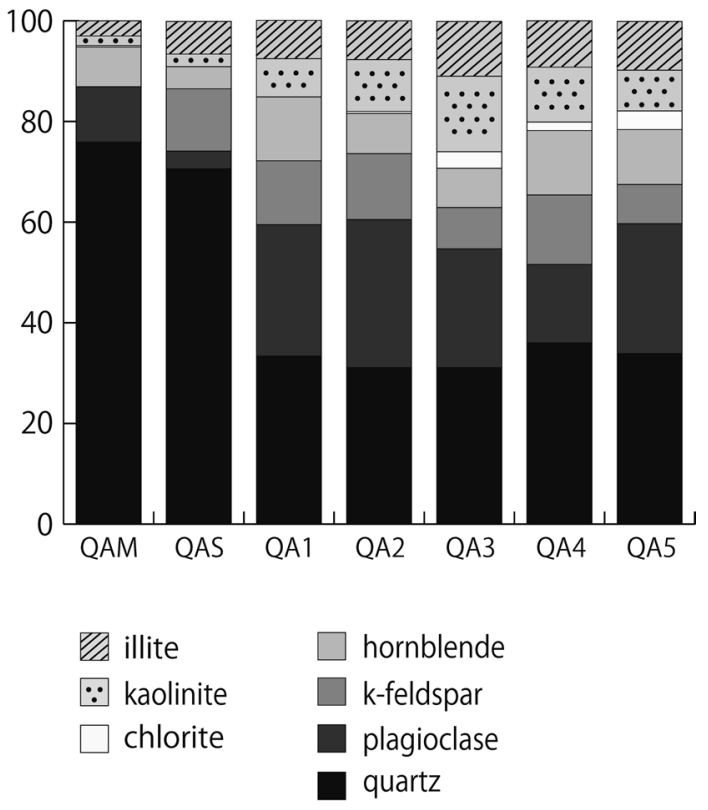

Fig. 4. Silicate mineral composition of cryoconite, soil, and moraine on and around Qaanaaq Glacier.

mineral content than the cryoconite from the other sites (Table 2).

The mineralogical composition of the soil and moraine around the Qaanaaq Glacier differed from that of the cryoconite (Table 2, Fig. 4). The soil and moraine showed a quartz content more than twice that of the cryoconite on the glacier, but a lower plagioclase and clay mineral content.

The mineral composition of the cryoconites showed substantial variations among the glaciers in northwest Greenland (Table 2, Fig. 5). The cryoconites from the Qaqortaq and Scarlet Heart Glacier showed a higher quartz content (65\% and $62 \%$ ), which was more than twice that of the other glaciers (22-38\%). The cryoconite from the Bowdoin Glacier also showed a higher potassium feldspar content (BD: $26 \%$, other glaciers: 8-18\%). However, the cryoconite from the Tugto Glacier showed a similar composition to that from the Qaanaaq Glacier. Furthermore, the clay mineral content also varied among the glaciers. The cryoconite from the Qaanaaq, Qaqortaq, Tugto and Sun Glaciers had a higher clay mineral content $(0-15 \%)$ than that from the Bowdoin and Scarlet Heart Glaciers (3-4\%).

\section{Discussion}

The XRD analysis revealed that the cryoconite on the glaciers in northwest Greenland mainly contained six silicate minerals, namely, hornblende, quartz, potassium feldspar, plagioclase, illite, and kaolinite, and also had a low chlorite content. The cryoconite on the Qaanaaq Glacier contained all the minerals and their composition and semi-quantitative proportions showed little variation
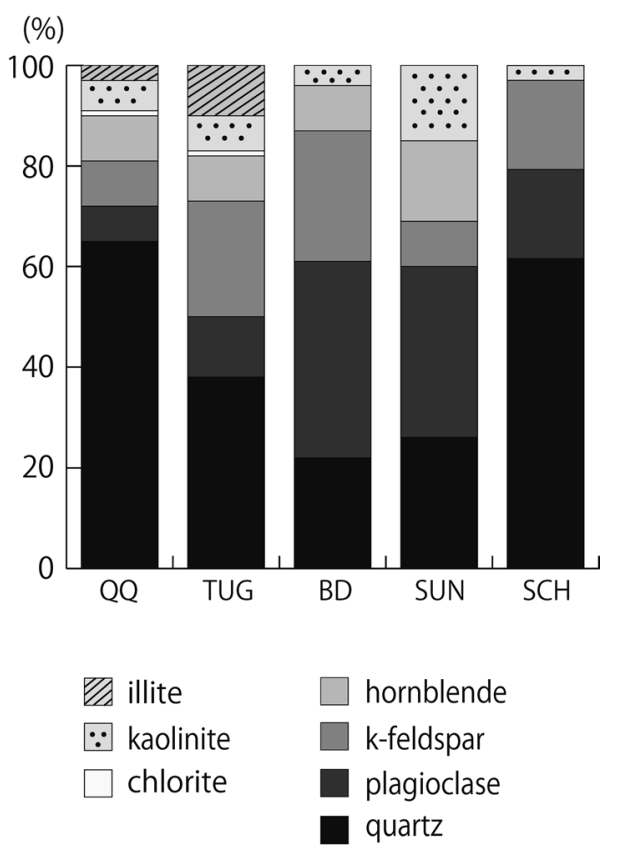

Fig. 5. Silicate mineral composition of cryoconites on glaciers in Greenland.

among the five samples collected from different elevations (Table 2, Fig. 2 and 4). This indicates that the silicate minerals in the cryoconite on the glacier were probably dominated by minerals derived from a unique source.

According to previous studies, there are three possible sources of minerals in cryoconite on glaciers in Greenland: (1) recent enhanced deposition of dust from the local area, probably the nearby tundra; (2) accumulation through melting of outcropping ice that contains old dust layers that were basally derived debris; or (3) long-range transported dust that settled on the higher parts of the ice sheet in the past (Bøggild et al., 2010; Wientjes and Oerlemans, 2010; Wientjes et al., 2011). The minerals in the cryoconite are likely to be a mixture of those from the three different sources. Bøggild et al. (2010) revealed that a glacial ice outcrop in northeast Greenland showed different mineralogical composition compared with the other ice areas, which were probably derived from Pleistocene glaciation. If the minerals derived from (2) or (3) were dominant in the cryoconite on the Qaanaaq Glacier, their composition would vary among the study sites. However, the silicate mineral composition and their relative abundance on the glacier were generally similar at all the sites, indicating that (1) the local dust recently transported was dominant in the cryoconite on the glacier. However, the minerals on the middle part of the glacier (QA3) contained a higher abundance of clay minerals than those on the other sites. This suggests that the possible sources of the silicate minerals on site QA3 were likely to be (2) or (3) dust from old ice.

The clay mineral composition in the cryoconite also supports the idea of local dust dominance on the Qaanaaq 
Glacier. Although these minerals in the cryoconite on the glacier are common in eolian dust, their composition, particularly the clay mineral content, differs from that of long-range transported dust. Compared with the composition of dust in the Greenland ice core derived from Asian deserts (Svensson et al., 2000), the proportion of clay minerals and plagioclase in the cryoconite were different. It was lower for clay minerals, but higher for plagioclase in the cryoconite than those of the ice core dust (clay minerals: $0-15 \%$ versus $37-68 \%$, plagioclase: 16-29\% versus $4-12 \%)$. The proportion of clay minerals in the cryoconite is also significantly lower than those of eolian dust from the desert in China (50-75\%), which contains similar silicate minerals to those in the dust on the glacier (Shen et al., 2009). Clay minerals are sorted and graded during long-range atmospheric transportation and tend to be concentrated in finer sediments like loess (Yokoo et al., 2004). According to the analysis of loess and sand from the Chinese desert, a change in mineral particle size from coarser to finer minerals owing to eolian sorting results in an increase in clay minerals with a lower quartz content (Honda et al., 2004; Kanayama et al., 2005). Therefore, the low clay mineral content of the cryoconite indicates that the silicate minerals on the glacier are mainly derived from local sources, rather than from distant areas.

Compared with the mineral composition of soil and moraine around the Qaanaaq Glacier, the proportion of clay minerals in the cryoconite was higher $(0-15 \%$ versus 0-7\%), although that of quartz was lower (31-36\%, 71$76 \%)$. The relative abundance of clay minerals to quartz is affected by chemical weathering as well as eolian sorting, because quartz is more stable than the other minerals and is thus resistant to weathering (Yokoo et al., 2004; Kanayama et al., 2005). Therefore, this compositional trend suggests that the silicate minerals in the cryoconite were likely to be weathered from those in the local sediments around the glacier.

The proportion of each silicate mineral in the cryoconites showed significant variation among the glaciers (Table 2, Fig. 5). Based on the semi-quantitative proportions, the cryoconites could be classified into three groups; Type A: abundant clay minerals composed of illite and kaolinite (Qaanaaq, Qaqortaq, Tugto), Type B: abundant clay minerals composed of only kaolinite (Sun), Type C: less abundant clay minerals composed of only kaolinite (Bowdoin, Scarlet Heart). Furthermore, the clay minerals content was lower (0-15\%) and the plagioclase content was higher (10-39\%) in all the cryoconites as they were on the Qaanaaq Glacier. These results indicate that the silicate minerals in the cryoconite on the glaciers were probably derived from the local area, but from different sources. Previous studies report that there is large spatial variation in the geology of Greenland; the geological development spans a period of 4 billion years (Ga), from the earliest Archaean to the Quaternary, and the lithology is dominated by the crystalline rocks of the Precambrian shield (Henriksen $e$ t al., 1995). Thomassen et al. (2002) showed that the geological conditions (lithology or minerals forming the bedrock) also vary among the areas around the peninsula where the glaciers are located (Fig. 1). For example, the Baffin Bay Group and Nare Strait Group, which consist of shallow water sedimentary rocks and volcanic rocks containing abundant $\mathrm{Cu}$, respectively, cover most of the peninsula. However, the other two geological units, the Prudhoe Land supracrustal complex, which is characterized by red and yellow rust zones in sulphidic semi-pelitic schist, and the Thule mixed-gneiss complex, which mainly consists of magnetite, silicate, and quartz, are widespread in the coastal areas facing Bowdoin Fjord (Fig. 1, Thomassen et al., 2002). Compared with the geology around the glaciers, the classification of the cryoconites based on the mineral composition did not necessarily correspond to that based on the geological units. For example, the Tugto Glacier (Type A) and the Bowdoin and Scarlet Heart Glacier (Type C) belong to different compositional groups, although they lie on the same geologic unit (Thule mixed-gneiss complex). This indicates that the mineralogical composition in the cryoconites is probably affected both by the geological conditions around the glaciers and by other factors, such as the redistribution of sediments by glacial, fluvial, or coastal processes.

The compositional variation in the silicate minerals may affect the surface albedo of the glaciers. Bøggild et al. (2010) revealed that cryoconite consisted of locally derived wind-blown sediments, which contributed greatly to the lowering of the surface albedo of the northeast Greenland ice sheet. Because colored minerals, which can cause glacial albedo reduction, are mainly composed of amorphous minerals, they cannot be fully identified by the XRD analysis. However, the compositional variation in the silicate minerals analyzed in this study suggests that the colored minerals contained in the samples also vary because they are likely to be derived from different sources. In fact, the cryoconite on the Qaqortaq Glacier appears more reddish than that on the other five glaciers (Takeuchi et al., 2014). Therefore, the minerals derived from different sources in northwest Greenland may have a different effect on the surface albedo of each glacier. It has been assumed that the mineralogical composition is uniform in each part of the world, such as the Arctic, Antarctica, and deserts, and thus the absorption characteristics of the mineral dust derived from the same regions has been modeled as having the same values in albedo models (Hess et al., 1998; Aoki et al., 2005). Therefore, considering the variations in the mineral composition on the glaciers is important for a more accurate assessment of the albedo reduction effect of the minerals.

The variations in the clay mineral composition also possibly account for the abundance of microbes on the glaciers. Tazaki et al. (1994) analyzed components of snow algae collected from Canadian Arctic that indicated 
that clay minerals might provide nutrients for the microbes. Thus, large variations in the clay mineral composition among the glaciers are likely to have an effect on the nutrient conditions and the abundance of microbes on each glacier. According to Uetake et al. (2010), the amounts of both organic matter (glacial microbes) and inorganic matter (minerals) on the Qaanaaq Glacier were higher at the intermediate altitude (QA3) than at the other sites. Furthermore, the proportion of cyanobacteria within the total algal biovolume was also highest at the QA3 site (Uetake et al., 2010). This trend is similar to that of the clay mineral proportion in the cryoconites, suggesting that the clay minerals may affect the abundance and community structure of the glacial microbes. According to previous work on glaciers in Asia (Nagatsuka et al., 2014), the mineral compositions in the cryoconites vary according to the geographical location of the glaciers and this variation of the minerals can affect the nutrient conditions of the glacial microbes. Therefore, the variations in the mineral composition in northwest Greenland are also likely to affect the microbial activity and also the surface albedo of the glaciers.

\section{Conclusions}

The cryoconite on six glaciers in northwest Greenland mainly consisted of seven kinds of silicate minerals: hornblende, quartz, potassium feldspar, plagioclase, including the clay minerals, illite, kaolinite, and chlorite. The mineralogical composition in the cryoconite on the Qaanaaq Glacier showed little variation among the samples collected from different elevations, indicating that the silicate minerals in cryoconite on the glacier were probably dominated by minerals derived from a unique source. The clay mineral content in cryoconite on the Qaanaaq Glacier was significantly lower than those of the eolian dust, suggesting that the minerals on the glacier are mainly derived from local sediments, probably soil and moraine, rather than from distant areas.

The mineral composition in cryoconites on the other glaciers in northwest Greenland also showed a lower clay mineral content compared with the eolian dust, although their relative proportions differed significantly among the glaciers. Based on the proportion of the clay minerals in the cryoconites, the glaciers were classified into three groups. The geographical locations of each group did not correspond with the geological conditions in this area, indicating that the mineralogical composition in the cryoconites is not just determined by the geological conditions around the glaciers, but also by other factors on and around the glaciers.

Our study demonstrates that there are large variations in the mineralogical composition in cryoconites among glaciers in northwest Greenland. Further analyses are necessary to identify the main factors determining the variation in the mineral composition and to quantify the albedo reduction effect of the minerals in cryoconites.

\section{Acknowledgements}

We would like to thank Dr. Noboru Furukawa of Chiba University for helping with XRD analysis. We would also like to thank Teruo Aoki for leading the project of Snow Impurity and Glacial Microbe effects on abrupt warming in the Arctic (SIGMA). We also would thank to members of the SIGMA and GRENE projects for their support in the field campaign of 2012 and 2013. Helpful comments and suggestions from three anonymous reviewers and the scientific editor $\mathrm{M}$. Hori are greatly appreciated. This study was financially supported by a Grant-in-Aid for Scientific Research (S, No. 23221004), Grant-in-Aid for JSPS Fellows, Green Network of Excellence (GRENE) Arctic Climate Change Research Project, and an NIPR publication subsidy.

\section{References}

Anesio, A. M., Hodson, A. J., Fritz, A., Psenner, R., and Sattler, B. (2009): High microbial activity on glaciers: importance to the global carbon cycle. Global Change Biol., 15 (4), 955-960, doi: 10.1111/j.1365-2486.2008.01758.x

Aoki, T., Tanaka, T.Y., Uchiyama, A., Chiba, M., Mikami, M., Yabuki, S., and Key, J.R. (2005): Sensitivity experiments of direct radiative forcing caused by mineral dust simulated with a chemical transport model. J. Meteor. Soc. Japan, 83A, 315-331, doi: 10.2151/jmsj.83A.315.

Bøggild, C. E., Brandt, R. E., Brown, K. J., and Warren, S. G. (2010): The ablation zone in northeast Greenland: ice types, albedos and impurities. J. Glaciol., 56, 101-113, doi: 10.3189/002214310791190776.

Bullard, J. E. and Austin, M. J. (2011): Dust generation on a proglacial floodplain, West Greenland. Aeolian Res., 3, 43-54, doi: 10.1016/j.aeolia.2011.01.002.

Chung, F. H. (1974): Quantitative interpretation of X-ray diffraction patterns. I. Matrix-flushing method of quantitative multicomponent analysis. J. Appl. Cryst., 7, 519-525, doi: $10.1107 / \mathrm{S} 0021889874010375$

Chung, F. H. (1975): Quantitative interpretation of X-ray diffraction patterns. III. Simultaneous determination of a set of reference intensities. J. Appl. Cryst., 8, 17-19, doi: 10.1107/ S0021889875009454.

Fjerdingstad, E. (1973): Accumulated concentrations of heavy metals in red snow algae in Greenland. Schweizerische Z. Hydrol., 35 (2), 247-251, doi: 10.1007/BF02502920.

Henriksen, N., Higgins, A. K., Kalsbeek, F., and Pulvertaft, T. C. R. (1995): Geological map of Greenland, 1:2500000. 2nd edition Geol. Surv. Denmark \& Greenland Bull., 18, 126.

Hess, M., Koepke, P., and Schult, I. (1998): Optical properties of aerosols and clouds: The software package OPAC. Bull. Am. Met. Soc., 79, 831-844, doi: 10.1175/1520-0477(1998)079 $<0831$ :OPOAAC $>2.0 . \mathrm{CO} ; 2$.

Hodson, A. J., Bøggild, C. E., Hanna, E., Huybrechts, P., Langford, H., Cameron, K., and Houldsworth, A. (2010): The cryoconite ecosystem on the Greenland ice sheet. Ann. Glaciol., 51(56), 123-129, doi: 10.3189/172756411795931985.

Honda, M., Yabuki, S., and Shimizu, H. (2004): Geochemical and isotopic studies of aeolian sediments in China. Sedimentology., 51, 211-230, doi: 10.1111/j.1365-3091.2004.00618.x.

IPCC (2007): Contribution of Working Group I to the Fourth Assessment Report of the Intergovernmental Panel on Climate Change. Solomon, S., Qin, D., Manning, M., Chen, Z., Marquis, M., Averyt, K.B., Tignor, M., and Miller, H.L. (Eds.), Cambridge University Press.

Jansson, P., Rosqvist, G., and Schneider, T. (2005); Glacier 
fluctuations, suspended sediment flux and glacio-lacustrine sediments. Geografiska Annaler., 87A, 37-50, doi: 10.1111/ j.0435-3676.2005.00243.x.

Kanayama, S., Yabuki, S., Liu, M., Shen, Z., Liu, L., Yanagisawa, F., and Abe, O. (2005): Size-dependent geochemical characteristics of asian dust - $\mathrm{Sr}$ and $\mathrm{Nd}$ isotope compositions as tracers for source identification. J. Meteorol. Soc. Jpn., 83A, 107-120, doi: 10.2151/jmsj.83A.107.

Kohshima, S., Seko, K., and Yoshimura, Y. (1993): Biotic acceleration of glacier melting in Yala Glacier, Langtang region, Nepal Himalaya. IAHS Publ., 218 (Symposium at Kathmandu 1992 -Snow and Glacier Hydrology), 309-316.

Kurosaki, Y. and Mikami, M., (2003): Recent frequent dust events and their relation to surface wind in East Asia. Geophys. Res. Lett., 30 (14), 1736, doi: 10.1029/2003GL017261.

Nagatsuka, N., Takeuchi, N., Nakano, T., Kokado, E., and Li, Z. (2010): $\mathrm{Sr}, \mathrm{Nd}$, and $\mathrm{Pb}$ stable isotopes of surface dust on Urumqi glacier No.1 in western China. Ann. Glaciol., 51 (56), 95-105, doi: 10.3189/172756411795931895.

Nagatsuka, N., Takeuchi, N., Nakano, T., Shin, K., and Kokado, E. (2014): Geographical variations in $\mathrm{Sr}$ and Nd isotopic ratios of cryoconite on Asian glaciers. Environ. Res. Lett., 9 (4), 045007, doi:10.1088/1748-9326/9/4/045007.

Oerlemans, J., Giessen, R. H., and van den Broeke, M. R. (2009): Retreating alpine glaciers: Increased melt rates due to accumulation of dust (Vadret da. Morteratsch, Switzerland). J. Glaciol., 55 (192), 729-736, doi: 10.3189/002214309789470969.

Shen, Z.X., Sandrine, C., Cao, J.J., Zhang, X.Y., Han, Y.M., Annie, G and Laurent, G. (2009): Mineralogical Characteristics of Soil Dust from Source Regions in Northern China. Particuology., 7, 507-512, doi: 10.1016/j.partic.2009.10.001.

Stibal, M., Telling, J., Cook, J., Mak, K. M., Hodson, A., and Anesio, A. M. (2012): Environmental controls on microbial abundance and activity on the greenland ice sheet: a multivariate analysis approach, Microb. Ecol., 63, 74-84, doi: 10.1007/s00248011-9935-3.

Sugden, D.E., McCulloch, R.D., Bory, A.J.-M, and Hein, A.S. (2009): Influence of Patagonian glaciers on Antarctic dust deposition during the last glacial period. Nat. Geosci., doi: 10.1038/NGEO474

Svensson, A., Biscaye, P. E., and Grousset, F. E. (2000): Character- ization of late glacial continental dust in the greenland ice core project ice core. J. Geophys. Res., 105 (D4), 4637-4656, doi: 10.1029/1999JD901093.

Takeuchi, N., Kohshima, S., and Seko, K. (2001): Structure, formation, and darkening process of albedo - reducing material (cryoconite) on a himalayan glacier: a granular algal mat growing on the glacier. Arctic, Arct. Antarct. Alp. Res., 33 (2), 115-122, doi: 10.2307/1552211.

Takeuchi, N., Nagatsuka, N., Uetake, J., and Shimada, R. (2014): Spatial variations in impurities (cryoconite) on glaciers in northwest Greenland. Bull, Glaciol. Res., 32, 85-94, doi: 10.5331/bgr.32.85

Tazaki, K., Fyfe, W. S., Iizumi, S., Sampei, Y., Watanabe, H., Goto, M., Miyake, Y., and Noda, S. (1994): Clay aerosols and arctic ice algae. Clays Clay Miner., 42, 402-408, doi: 10.1346/ CCMN.1994.0420404.

Thomassen, B., Dawes, R. B., Steenfelt, A., and Krebs, D. J. (2002): Qaanaaq 2001: mineral exploration reconnaissance in North-West Greenland. Geol. Greenland Surv. Bull., (191), 133-143.

Uetake, J., Naganuma, T., Hebsgaard, M. B., and Kanda, H. (2010): Communities of algae and cyanobacteria on glaciers in west Greenland. Polar Sci., 4, 71-80, doi: 10.1016/j. polar.2010.03.002.

VanCuren, R. A. and Cahill, T. A., (2002): Asian aerosols in North America: Frequency and concentration of fine dust. $J$. Geophys. Res., 107 (D24), 4804, doi: 10.1029/2002JD002204.

Wientjes, I.G.M., and Oerlemans, J., (2010): An explanation for the dark region in the western melt zone of the Greenland ice sheet. Cryosphere., 4 (3), 261-268, doi: 10.5194/tc-4-261-2010.

Wientjes, I. G. M., van de Wal, R. S. W., Reichart, G. J., Sluijs, A., and Oerlemans, J., (2011): Dust from the dark region in the western ablation zone of the Greenland ice sheet. Cryosphere., 5, 589-601, doi: 10.5194/tc-5-589-2011.

Yokoo, Y., Nakano, T., Nishikawa, M. and Quan, H. (2004): Mineralogical variation of $\mathrm{Sr}-\mathrm{Nd}$ isotopic and elemental compositions in loess and desert sand from the central Loess Plateau in China as a provenance tracer of wet and dry deposition in the northwestern Pacific. Chem. Geol., 204, 4562, doi: 10.1016/j.chemgeo.2003.11.004. 